\title{
PENGARUH PENDIDIKAN AGAMA KRISTEN DALAM KELUARGA DAN RUTINITAS KEGIATAN IBADAH DI SEKOLAH TERHADAP PEMBENTUKAN MORAL SISWA DI SEKOLAH MENENGAH PERTAMA NEGERI 2 PANCUR BATU
}

\author{
Pitri Sartika Sihotang, Hermanto Sihotang, Risa Ariska Tarigan \\ pitrisihotang@gmail.com, sihotanghermanto@gmail.com, risatarigan@gmail.com \\ Sekolah Tinggi Teologi Sumatera Utara
}

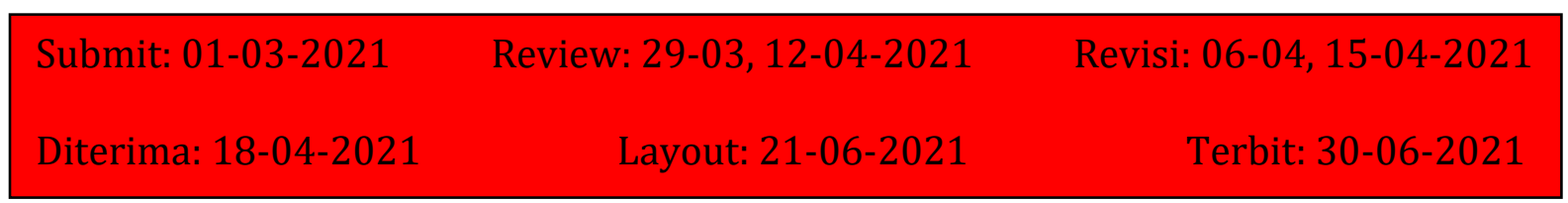

\begin{abstract}
This study investigates the influence of Christian religious education in families and worship activities in schools on moral formation for students. Researchers have noticed that PAK teaching activities in families are a separate asset in the field of PAK. An activity that has a tremendous impact on future generations. Besides, routine worship activities in schools also need attention from all parties, namely parents, teachers, and the community. of course not forgetting for the students themselves. Meanwhile, moral which is often equated with the formation of one's cognition, affection, and ethical behavior cannot be taken for granted. This must be formed in a time trajectory that requires energy, time thought, energy, money, and concentration to achieve an ideal moral form, especially from a Christian perspective. The method used is field research with post ex facto. From the data entered, it was found that the variable tendency was high, namely PAK Keluarga (X1) by 91\%, student worship routines (X1) by 94\%, and 97\% for the formation of student morality (Y). Thus the proposed hypothesis has been answered through research. Therefore, religious education activities in the family and worship in schools need to be carried out regularly to obtain good morality for students. All parties should take this effort more seriously from the perspective of Christian morality formation.
\end{abstract}

Keywords: Christian religious education in families; worship activities in schools; moral

\begin{abstract}
Abstrak
Penelitian ini mencari pengaruh dari pendidikan agama Kristen di Keluarga dan kegiatan ibadah di sekolah terhadap pembentukan moral bagi siswa. Peneliti memperhatikan bahwa kegiatan pengajaran PAK di Keluarga satu harta tersendiri dalam bidang PAK. Kegiatan yang memiliki dampak luar biasa bagi generasi masa depan. Di samping itu kegiatan ibadah rutin di sekolah juga perlu mendapat perhatian dari semua pihak, yakni orang tua, guru dan masyarakat. Tentu tidak lupa bagi siswa itu sendiri. Sedangkan moral yang sering dipersamakan dengan pembentukan kognisi, afeksi dan perilaku etis seseorang tidak dapat diperoleh begitu saja. Hal ini harus dibentuk dalam lintasan waktu yang membutuhkan energy, waktu, pikiran, tenaga, uang dan konsentrasi demi meraih bentuk moral yang ideal khususnya dalam persfektif Kristen. Metode yang digunakan adalah penelitian lapangan dengan post ex facto. Dari data yang masuk diperoleh kecenderungan variable yang tinggi yakni PAK Keluarga (X1) sebesar 91\%, rutinitas ibadah siswa (X1) sebesar 94\% dan 97\% untuk pembentukan moralitas siswa (Y).
\end{abstract}


Dengan demikian hipotesa yang diajukan telah terjawab melalui penelitian. Karena itu kegiatan pendidikan agama di keluarga dan ibadah di sekolah perlu dilakukan secara rutin untuk memperoleh moralitas yang baik bagi siswa. Semua pihak hendaknya memperhatikan upaya ini dengan lebih sungguh-sungguh dari persfektif pembentukan moral kristiani.

Kata Kunci: PAK Keluarga; ibadah siswa; moral

\section{Pendahuluan}

Pada tahun ini Rahman memberikan ulasan terkait moral dan keberagamaan di kalangan siswa. Secara khusus dengan perhatian pada upaya menciptakan semangat hidup rukun diantara siswa yang berbeda agama. Rahman memberikan penekanan untuk menghargai perbedaan dan menghormati sesama ciptaan Allah Yang Maha kuasa, ${ }^{1}$ sebab itu adalah cerminan isi hati Allah. Sebab itu rahman mendoronga agar ajaran agama memberikan cakupan pada moral siswa dalam rangka mendorong kerukunan. Dalam memasuki era pandemi juga ada penelitian dalam jurnal dan publikasi lainnya yang menyoroti etika pekerja, murid, siswa dan mahasiswa dengan mempertautkan pada praktik moralnya. Kassa memperhatikan moral yang telah tumbuh dalam diri ASN sejak sekolah hingga menjadi pekerja tampak dalam kinerja di lapangan dalam berbagai situasi yang dialami. ${ }^{2}$ Kassa mengulas pentingnya penanaman nilai-nilai moral kepada pekerja sejak dini untuk mendapatkan hasil yang maksimal pada masa dewasa. Karena itu dati dua literature tersebut dapat ditekankan bahwa penanaman nilai moral bagi siswa di sekolah sangat mempegaruhi masa depannya kelak. Dengan demikian, anak memberikan satu modal tersendiri untuk masuk dalam persaingan di masa depan karena anak-anak dengan moral dan karakter yang baik mampu berinteraksi di masyarakat, ${ }^{3}$ memilah mana yang baik dan jahat serta mempunyai iman teguh kepada Tuhan.

Di kalangan anak sekolah SMP Negeri 2 Pancur Batu yang sedang mengalami peralihan masa dari anak-anak menuju remaja. Dimana sikap dan perbuatan mereka sering dipengaruhi oleh suasana orang-orang di sekelilingnya. Mereka bukan hanya dipengaruhi suasana yang ada dalam keluarganya, mereka juga dipengaruhi oleh lingkungan, tempat mereka hidup dan bertumbuh. Anak remaja ini apabila hidup dan bertumbuh dalam lingkungan yang baik rohaninya kepada Tuhan maka dengan sendirinya akan memiliki sikap etis yang baik pula. Dengan program-program mentoring melalui ekstrakurikuler, sebab padanya melekat hak dan kewajiban untuk memantau anak didik. ${ }^{4}$ Oleh karena anak SMP yang sedang meninggalkan masa kanakkanak dan beralih kepada masa remaja, maka rasa antusiasme mereka begitu menggebu-gebu. Mereka ingin mencoba segala pilihan dan kemungkinan yang diperhadapkan kepada mereka, dan banyak anak SMP sulit mengendalikan diri atau memilih mana yang baik, sehingga banyak mereka yang tidak memiliki dengan baik sikap etisnya, sikap dan tingkah laku anak SMP yang menyimpang dari kehendak Tuhan.

\footnotetext{
${ }^{1}$ Yenni Rahman, Nilai-Nilai Agama Dan Moral: Kerukunan Beragama-Pegangan Murid/Anak (Tangerang: Tirtamedia, 2021), 51.

${ }^{2}$ Enos Bonny Kassa, Etika Dan Moral ASN Di Masa Pandemi Covid-19, ed. Wulansari Apriani (Bogor: CV. Dandelion Publisher, 2021).

${ }^{3}$ Hasahatan Hutahaean, Hermanto Sihotang, and Purnamasari Siagian, "PAK Dalam Keluarga Dan Lingkungan Pergaulan Siswa, Kontribusinya Terhadap Pembentukan Karakter," Berita Hidup 3, no. 2 (2021): 173, https://e-journal.sttberitahidup.ac.id/index.php/jbh/article/view/84.

${ }^{4}$ DADAN SUMARA SUMARA, SAHADI HUMAEDI, and MEILANNY BUDIARTI SANTOSO, “Kenakalan Remaja Dan Penanganannya," Prosiding Penelitian dan Pengabdian kepada Masyarakat 4, no. 2 (2017): 350 .
} 
Dalam situasi tersebut peneliti melihat peran pembinaan PAK dari orang tua di rumah perlu mendapat sorotan bagi pembentukan moral siswa. Selain pembinaan PAK orang tua peneliti menduga adanya pengaruh yang signifikan dari rutinitas Ibadah yang diselenggarakan di sekolah oleh siswa. Rutinitas Ibadah di sekolah sekali seminggu dan doa di kelas setiap pagi dan saat sebelum pulang memiliki andil tersendiri untuk membentuk moralitas siswa secara regular. Tentu ada banyak faktor yang patut untuk diperhitungkan namun dalam kesempatan ini peneliti fokus pada PAK Keluarga dan Rutinitas Ibadah terhadap pembentukan moral siswa.

Untuk mendapatkan data awal, peneliti melakukan wawancara tidak terstruktur ${ }^{5}$ kepada beberapa guru yang mengajar di SMP Negeri 2 Pancur Batu tersebut mengatakan 'banyaknya siswa yang terpengaruh oleh majunya zaman dengan canggihnya alat elektronik yang juga mempengaruhi banyaknya remaja yang tidak lagi memperdulikan bagaimana layaknya anak-anak sekolah yang mencerminkan moral yang baik dalam kehidupan mereka sebagai anak-anak Tuhan. Sehingga mencerminkan bahwa anak-anak SMP itu tidak memiliki pembentukan moral yang baik'.

Hasil observasi peneliti di lingkungan sekolah ada beberapa contoh bukti remaja yang mengabaikan penghormatan terhadap guru. Siswa menjawab dengan pertanyaan guru dengan suara yang besar, dengan mengucapkan kata-kata yang kurang sopan kepada sesama teman sekolahnya di dalam atau di luar sekolah. Selain itu, banyak juga siswa yang berpakaian tidak sopan dan tidak rapi. Seperti perempuan memakai rok yang pendek dan memakai baju sekolah yang ketat. Banyak juga siswa yang tidak disiplin terhadap waktu yang telah ditentukan sekolah. Dimana banyak siswa yang sering terlambat saat masuk ke sekolah. Menanggapi hal tersebut, sebagaimana yang dikemukakan oleh Sumara bahwa banyak contoh-contoh kenakalan anak dan perbuatan pelanggaran lainnya yang ternyata bersumber pada keadaan keluarga, yaitu suasana rumah, yang tidak menyokong perkembangan mereka, sehingga mereka menjadi anak atau orang dewasa yang tidak memiliki moral dan melakukan perbuatan anti sosial dan amoral. ${ }^{6}$ Siswa yang tinggal bersama keluarga tidak menjamin bahwa siswa tersebut memiliki moral yang baik, karena belum tentu dapat memberikan pendidikan yang baik dalam keluarga yang nantinya akan membentuk moral remaja.

Dari paparan di atas, dalam penelitian ini peneliti berangkat dari dugaan bahwa PAK di Keluarga dan Rutinitas Ibadah di Sekolah jika dilakukan dengan regular mampu mengambil bagian dalam pembentukan moralitas siswa. Untuk pembuktian hal itu akan dilanjutkan dengan penelitian di lapangan dengan mengambil sampel dan tempat yakni siswa/i Kristen kelas VII SMP Negeri 2 Pancur Batu.

\section{Metode Penelitian}

Adapun metode penelitian yang dilakukan oleh penulis adalah metode penelitian lapangan dengan "data berupa angka-angka" yang akan ditabulasi. ${ }^{7}$ Metode penelitian lapangan dipilih karena penulis bermaksud meneliti suasana dan situasi serta keadaan yang berlangsung di SMP Negeri 2 Pancur Batu. Penelitian lapangan ini dilaksanakan dengan pola ex post facto, karena peneliti mengkaji data yang telah berlalu namun masih

\footnotetext{
${ }^{5}$ Haddy Suprapto, Penerapan Metodologi Penelitian Dalam Karya Ilmiah (Yogyakarta: Gosyen Publishing, 2020), 67 Dari tiga uraian Suprapto, salah satu tujuannya adalah mendapatkan informasi agar peneliti dapat memformulasikan variabel.

${ }^{6}$ SUMARA, HUMAEDI, and SANTOSO, "Kenakalan Remaja Dan Penanganannya," 349.

${ }^{7}$ Baca. Whidmurni Whidmurni, "Penelitian Kuantitatif," Pemaparan Metode Penelitian Kuantitatif 2, no. 16 (2017): 1-2, http://repository.uin-malang.ac.id/1985/2/1985.pdf.
} 
PENGARUH PENDIDIKAN AGAMA KRISTEN DALAM KELUARGA ... (Pitri Sartika Sihotang, Hermanto Sihotang, Risa Ariska Tarigan

berlangsung sampai penelitian ini dilakukan. ${ }^{8}$

Seturut Sugiono ${ }^{9}$ maka populasi penelitian ini adalah seluruh siswa/i Kristen kelas VII SMP Negeri 2 Pancur Batu sebanyak 119 orang (7 kelas). Dari populasi yang ada diambil sebagai sampel sebagai wakil dari sampel yang diteliti. Menurut Arikunto ${ }^{10}$ sampel penelitian adalah sebesar 25\% dari 119 siswa (total sampel keseluruhan) $=30$ orang.

Adapun tehnik pengambilan sampel yang peneliti gunakan adalah dengan menggunakan metode Proportioned Stratified yang dikemukakan oleh Sugiyono ${ }^{11}$ dengan rumus sebagai berikut: $=\frac{\text { Jumlah.Populasi/Kelas }}{\text { TotalPopulasi }} \times$ TotalSampel
Keterangan
19 : Jumlah Siswa Kristen Kelas VII/Kelas
119 : Total Keseluruhan Siswa Kristen
30 : Total Sampel

Tabel 1 Sampel Penelitian

\begin{tabular}{|c|c|c|}
\hline KELAS & Jumlah Siswa & Sampel Uji Coba \\
\hline $\mathrm{VII}_{1}$ & 19 orang & 5 orang \\
\hline $\mathrm{VII}_{2}$ & 14 orang & 3 orang \\
\hline $\mathrm{VII}_{3}$ & 18 orang & 4 orang \\
\hline $\mathrm{VII}_{4}$ & 12 orang & 3 orang \\
\hline $\mathrm{VII}_{5}$ & 16 orang & 5 orang \\
\hline $\mathrm{VII}_{6}$ & 19 orang & 5 orang \\
\hline $\mathrm{VII}_{7}$ & 21 orang & 5 orang \\
\hline JUMLAH & 119 Orang & 30 orang \\
\hline
\end{tabular}

Instrument penelitian digunakan yakni angket yang bersifat tertutup yakni pernyataan sudah memiliki jawaban dengan 4 pilihan dan ketentuan penilaian dari setiap pilihan, yaitu sebagai berikut

Tabel 2 Skor Jawaban Angket

\begin{tabular}{|c|c|c|c|}
\hline \multicolumn{2}{|c|}{ Pernyataan Positif } & \multicolumn{2}{c|}{ Pernyataan Negatif } \\
\hline Jawaban & Skor & Jawaban & Skor \\
\hline Sangat Setuju (SS) & 4 & Sangat Setuju (SS) & 1 \\
\hline Setuju (S) & 3 & Setuju (S) & 2 \\
\hline Kurang Setuju (KS) & 2 & Kurang Setuju (KS) & 3 \\
\hline Tidak Setuju (TS) & 1 & Tidak Setuju (TS & 4 \\
\hline
\end{tabular}

Untuk penelitian ini diberikan tiga variable yakni PAK Keluarga $\left(\mathrm{X}_{1}\right)$, Rutinitas Beribadah Siswa $\left(\mathrm{X}_{2}\right)$ dan Pembentukan Moral Siswa (Y). masing-masing variable disusun angket dengan kisi-kisi seperti table berikut.

\section{Tabel 3 Kisi-Kisi Angket Variabel PAK Keluarga ( $\left.\mathrm{X}_{1}\right)$}

\footnotetext{
${ }^{8}$ Anthony A. Braga, David M. Hureau, and Andrew V. Papachristos, “An Ex Post Facto Evaluation Framework for Place-Based Police Interventions," Evaluation Review 35, no. 6 (2012): 592-626.

${ }^{9}$ Sugiyono Sugiyono, Metode Penelitian Kuantitatif (Bandung: AlfaBeta, 2018), 90.

${ }^{10}$ Suharsimi Arikunto, Prosedur Penelitian : Suatu Pendekatan Praktik (Edisi Revisi), Rineka Cipta, Revisi. (Jakarta: PT. Rineka Cipta, 2012), 112.

${ }^{11}$ Sugiyono, Metode Penelitian Kuantitatif, 102.
} 


\begin{tabular}{|c|c|c|c|}
\hline Variabel & Sub Variabel & Indikator & Item \\
\hline \multirow[t]{4}{*}{$\begin{array}{c}\text { PAK } \\
\text { KELUARGA }\end{array}$} & $\begin{array}{l}\text { Pengertian } \\
\text { PAK } \\
\text { Keluarga }\end{array}$ & $\begin{array}{l}\text { Keluarga dapat bertanggung } \\
\text { jawab terhadap perannya } \\
\text { masing-masing didalam keluarga } \\
\text { sesuai dengan Firman Tuhan }\end{array}$ & $1,5,8$ \\
\hline & $\begin{array}{l}\text { Fungsi dan } \\
\text { Peran } \\
\text { Keluarga }\end{array}$ & $\begin{array}{l}\text { 1. Siswa dapat menghormati dan } \\
\text { menghargai orangtua } \\
\text { 2. Siswa harus menjaga nama } \\
\text { baik keluarga. } \\
\text { 3. Keluarga saling melindungi } \\
\text { anggota keluarganya }\end{array}$ & $\begin{array}{l}2,4,10 \\
3,28,18 \\
7,11,20\end{array}$ \\
\hline & $\begin{array}{l}\text { PAK } \\
\text { Keluarga } \\
\text { Dalam } \\
\text { Alkitab }\end{array}$ & $\begin{array}{l}\text { 1. KKeluarga selalu terbuka akan } \\
\text { kehadiran Allah } \\
\text { 2. SSiswa mewujudkan tindakan } \\
\text { yang mencerminkan keluarga } \\
\text { Kristen yang berpegang pada } \\
\text { kebenaran Firman Tuhan. } \\
\text { 3. SSiswa menjadi teladan di } \\
\text { dalam lingkungannya. }\end{array}$ & $\begin{array}{l}6,22,30 \\
14,17 \\
25\end{array}$ \\
\hline & $\begin{array}{c}\text { Tujuan PAK } \\
\text { Keluarga }\end{array}$ & $\begin{array}{l}\text { 1. Anak-anak dapat mengenal } \\
\text { Tuhan lebih dalam } \\
\text { 2. Anak-anak mengerti } \\
\text { kebenaran Alkitab } \\
\text { 3. Lebih mengutamakan Tuhan } \\
\text { dalam hidupnya }\end{array}$ & $\begin{array}{c}13,19 \\
27 \\
9,15,29 \\
16,21 \\
23,26\end{array}$ \\
\hline & & JUMLAH & 30 \\
\hline
\end{tabular}

Tabel 4 Kisi-Kisi Angket Variabel Rutinitas Beribadah Siswa $\left(\mathrm{X}_{2}\right)$

\begin{tabular}{|c|c|c|c|}
\hline Variabel & Sub Variabel & Indikator & Item \\
\hline \multirow[t]{3}{*}{$\begin{array}{c}\text { Rutinitas } \\
\text { Beribadah } \\
\text { Siswa }\end{array}$} & $\begin{array}{l}\text { Pengertian } \\
\text { Rutinitas } \\
\text { Ibadah }\end{array}$ & $\begin{array}{l}\text { 1. Siswa menghormati Tuhan } \\
\text { melalui rutinitas ibadah } \\
\text { 2. Siswa tertib dalam } \\
\text { melakukan ibadah } \\
\text { 3. SSiswa melaksanakan } \\
\text { ibadah dengan kerelaan hati } \\
\text { bukan karena dipaksa }\end{array}$ & $\begin{array}{c}1,9 \\
5,20 \\
18,27\end{array}$ \\
\hline & $\begin{array}{l}\text { Ibadah } \\
\text { Menurut } \\
\text { Alkitab }\end{array}$ & 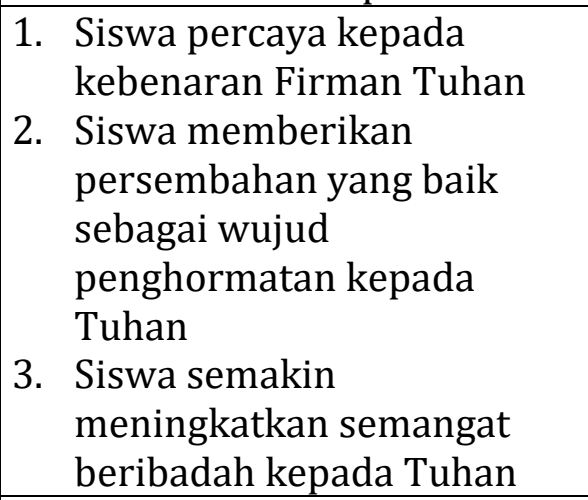 & $\begin{array}{l}2,10 \\
8,26\end{array}$ \\
\hline & Manfaat Dan & 1. Siswa percaya kepada & 15,21 \\
\hline
\end{tabular}




\begin{tabular}{|c|c|c|}
\hline $\begin{array}{l}\text { Tujuan } \\
\text { Ibadah Bagi } \\
\text { Siswa }\end{array}$ & $\begin{array}{l}\text { Tuhan sepenuhnya } \\
\text { 2. Siswa kuat dan tidak mudah } \\
\text { putus asa dalam } \\
\text { menghadapi masalah } \\
\text { 3. Siswa menjadi orang yang } \\
\text { penuh kasih dan lemah } \\
\text { lembut } \\
\text { 4. Siswa mengalami perubahan } \\
\text { dalam hidupnya ke arah } \\
\text { yang lebih baik } \\
\text { 5. Siswa semakin termotivasi } \\
\text { untuk ikut serta dalam } \\
\text { pelayanan ibadah }\end{array}$ & $\begin{array}{c}7,12 \\
16,30 \\
6,13,22 \\
11,19,29\end{array}$ \\
\hline $\begin{array}{l}\text { Sikap Ibadah } \\
\text { Yang Salah } \\
\text { Dan Benar }\end{array}$ & $\begin{array}{l}\text { 1. Siswa melaksanakan ibadah } \\
\text { bukan sekedar rutinitas } \\
\text { sebagai orang Kristen } \\
\text { 2. Siswa melaksanakan ibadah } \\
\text { dengan motivasi yang benar } \\
\text { 3. Siswa memusatkan } \\
\text { perhatiannya kepada Tuhan } \\
\text { saat beribadah } \\
\text { 4. Siswa mengikuti ibadah } \\
\text { yang berlangsung sampai } \\
\text { selesai }\end{array}$ & $\begin{array}{c}4 \\
17,28 \\
23,25 \\
24\end{array}$ \\
\hline & JUMLAH & 30 \\
\hline
\end{tabular}

Tabel 5 Kisi-Kisi Angket Variabel Pembentukan Moral Siswa (Y)

\begin{tabular}{|c|c|c|c|}
\hline Variabel & Sub Variabel & Indikator & Item \\
\hline \multirow[t]{3}{*}{$\begin{array}{l}\text { Pembentuk } \\
\text { an Moral } \\
\text { Siswa }\end{array}$} & $\begin{array}{l}\text { Pengertian } \\
\text { Pembentuka } \\
\text { n Moral }\end{array}$ & $\begin{array}{l}\text { 1. Siswa dapat menjaga } \\
\text { sikapnya baik dilingkungan } \\
\text { sekolah, keluarga, dan } \\
\text { masyarakat sesuai normal } \\
\text { yang berlaku } \\
\text { 2. Siswa berbicara santun } \\
\text { kepada orang lain } \\
\end{array}$ & $6,19,25$ \\
\hline & $\begin{array}{l}\text { Tahap } \\
\text { Perkembang } \\
\text { an Moral }\end{array}$ & $\begin{array}{l}\text { 1. Siswa dapat membedakan } \\
\text { mana yang baik dan buruk } \\
\text { 2. Siswa mentaati peraturan } \\
\text { disekolah dan dilingkungan } \\
\text { 3. Siswa memiliki komitmen } \\
\text { untuk dapat melakukan } \\
\text { tindakan baik dan } \\
\text { menjauhkan segala tindakan } \\
\text { buruk }\end{array}$ & $\begin{array}{c}13,22 \\
4,24 \\
2,18,27\end{array}$ \\
\hline & $\begin{array}{l}\text { Faktor Yang } \\
\text { Mempengaru } \\
\text { hi } \\
\text { Perkembang } \\
\text { an Moral } \\
\end{array}$ & $\begin{array}{l}\text { 1. Siswa dapat memanfaatkan } \\
\text { perkembangan IPTEK dengan } \\
\text { baik } \\
\text { 2. Siswa dapat menjauhi } \\
\text { pergaulan buruk di }\end{array}$ & $\begin{array}{l}3,11,21 \\
5,14,23 \\
7,12,29\end{array}$ \\
\hline
\end{tabular}




\begin{tabular}{|c|c|c|}
\hline & $\begin{array}{l}\text { lingkungannya } \\
\text { 3. Siswa dapat melakukan } \\
\text { kegiatan positif }\end{array}$ & \\
\hline $\begin{array}{l}\text { Dasar Alkitab } \\
\text { Tentang } \\
\text { Moral }\end{array}$ & $\begin{array}{l}\text { 1. Siswa dapat setia terhadap } \\
\text { ajaran Tuhan Yesus } \\
\text { 2. Siswa dapat menghindari } \\
\text { pelanggaran yang melanggar } \\
\text { norma Alkitab } \\
\text { 3. Siswa dapat mengikuti ajaran } \\
\text { yang Yesus berikan }\end{array}$ & $\begin{array}{r}8,15,26 \\
9,17,28 \\
16,30\end{array}$ \\
\hline & JUMLAH & 30 \\
\hline
\end{tabular}

Untuk mengetahui reliabilitas (keterhandalan) angket untuk digunakan rumus Kuder Richardson:

$$
r_{i i}=\left(\frac{K}{K-1}\right)\left(1 \frac{\sum \sigma^{-2}}{\sum \sigma i^{2}}\right)
$$

Keterangan:

$$
\begin{array}{ll}
r_{i i} & =\text { Reliabilitas Instrumen } \\
\mathrm{K} & =\text { Banyaknya Butir Soal } \\
\sum \sigma^{-2} & =\text { Jumlah Varian Butir Item } \\
\sum \sigma^{2} & =\text { Jumlah Varian Total }
\end{array}
$$

Tabel 6 Interprestasi nilai r Suharsimi Arikunto

\begin{tabular}{|c|c|}
\hline Besarnya nilai r & Interprestasi \\
\hline $0,600-0,799$ & Tinggi \\
\hline $0,400-0,599$ & Cukup Tinggi \\
\hline $0,200-0,399$ & Rendah \\
\hline $0,000-0,199$ & Sangat Rendah \\
\hline
\end{tabular}

Kriteria uji ril memenuhi persyaratan apabila rh (rhitung) dengan ketetapan reliabilitas berada pada batas 0,400-1,000. Ketetapan reliabilitas dapat dilihat yang cocok dengan harga yang dibuat oleh Suharsimi Arikunto ${ }^{12}$ setelah diadakan perhitungan reliabilitas item angket yang valid.

Setelah data dideskripsikan, selanjutnya akan didakan uji linearitas. Uji liniaritas dilakukan dengan uji regresi liniear sederhana yaitu $\mathrm{Y}$ atas $\mathrm{X}\left(\mathrm{X}_{1}\right.$ dan $\left.\mathrm{X}_{2}\right)$ dimana persamaan regresi sederhana yaitu $\mathrm{Y}=\mathrm{a}+\mathrm{bX} \mathrm{X}_{1}$ dan, $\mathrm{Y}=\mathrm{a}+\mathrm{bX} \mathrm{X}_{2}$. Untuk mencari a (bilangan konstanta) dan b (bilangan koefisien predictor). Dengan rumus sebagai berikut:

$$
\begin{aligned}
& a=\frac{\left(\sum Y\right)\left(\sum X\right)^{2}-\left(\sum X\right)\left(\sum X Y\right)}{N \sum X^{2}-\left(\sum X\right)^{2}} \\
& b=\frac{N\left(\sum X Y\right)-\left(\sum X\right)\left(\sum Y\right)}{N \sum X^{2}-\left(\sum X\right)^{2}}
\end{aligned}
$$

Keterangan:

\footnotetext{
${ }^{12}$ Arikunto, Prosedur Penelitian : Suatu Pendekatan Praktik (Edisi Revisi), 79.
} 
PENGARUH PENDIDIKAN AGAMA KRISTEN DALAM KELUARGA ... (Pitri Sartika Sihotang, Hermanto Sihotang, Risa Ariska Tarigan

$$
\begin{aligned}
\mathrm{Y} & =\text { Nilai yang diprediksi } \\
\mathrm{a} & =\text { konstanta } \\
\mathrm{b} & =\text { Koefisien Regresi } \\
\mathrm{X} & =\text { Nilai Variabel Bebas }
\end{aligned}
$$

Dari latar belakang dan metode yang digunakan peneliti merumuskan hipotesa yaitu;

1. Terdapat kontribusi yang berarti dari PAK Keluarga terhadap Pembentukan Moral Siswa kelas VII SMP Negeri 2 Pancur Batu Tahun 2020

2. Terdapat kontribusi yang berarti dari Rutinitas Ibadah Siswa terhadap Pembentukan Moral Siswa kelas VII SMP Negeri 2 Pancur Batu Tahun 2020

3. Terdapat kontribusi yang berarti dari PAK Keluarga dan Rutinitas Ibadah siswa secara bersama-sama terhadap Pembentukan Moral Siswa kelas VII SMP Negeri 2 Pancur Batu Tahun 2020

\section{Pembahasan}

\section{Pembentukan Moral (Y)}

Kata mores (bhs Latin) artinya tata cara dalam kehidupan, bisa juga adat istiadat atau kebiasaan. Kamus Besar Bahasa Indonesia online, menyatakan bahwa moral merupakan ajaran baik atau buruk yang diterima, secara umum. Bagi Samsuri dan Muchson ada istilah yang dikaitkan dengan kata moral misalnya: susila, etika, karakter, budi pekerti dan akhlak, afeksi dan mempelajari masalah kognisi. ${ }^{13}$ Bertens memberikan penekanan tentang pembahasan terhadap bidang etika dan atau moral seringkali berkaitan dengan hal-hal yang sangat penting. ${ }^{14}$

Adapun etika biasanya secara sempit dikaitkan sangat erat dengan moral (Mos') dan bentuk jamaknya 'Moris', yang berarti juga adat kebiasaan atau cara hidup seseorang dengan melakukan perbuatan yang baik (kesusilaan), dan menghindari halhal tindakan yang buruk. Moral secara objektif adalah relasi antara perbuatan manusia dengan tujuan akhir hidupnya seturut nilai keagamaan dan nilai-nilai umum yang berlaku. Perbuatan seseorang dikatakan moralnya baik apabila perbuatanperbuatannya dinilai baik juga dalam lingkungannya. ${ }^{15}$ Lebih tegas lagi Bertens memberikan ulasannya bahwa etika memandang sesuatu itu baik atau tidak baik bukan dari sisi estetika, tehnis pratis yang tampak atau dari sisi kemampuan finansial, namun dari sudut pandang moral. ${ }^{16}$ Dari pengertian moral di atas, dapat diartikan moralitas merupakan kemauan untuk menerima dan melakukan peraturan, nilai-nilai atau prinsip-prinsip moral yang akan dilakukan dalam sikap etis seseorang terhadap kehidupannya sebagai orang yang memiliki moral.

Etika dan moral lebih kurang sama pengertiannya, namun bagi Cyr dan Flummer dalam kegiatan sehari-hari terdapat perbedaan, yaitu moral atau moralitas untuk penilaian perbuatan yang dilakukan, sedangkan etika adalah untuk pengkajian sistem nilai-nilai yang berlaku. ${ }^{17}$ Karena itu dapat ditambahkan bahwa moral dipakai untuk perbuatan yang sedang dinilai, sedangkan etika dipakai dipakai untuk pengkajian sistem nilai-nilai yang ada.

\footnotetext{
${ }^{13}$ Muchson AR and Samsuri Samsuri, DASAR-DASAR PENDIDIKAN MORAL (Yogyakarta: Penerbit OMBAK, 2013), 41.

${ }^{14}$ K Bertens, Etika, Kesepuluh. (Jakarta: PT Gramedia Pustaka Utama, 2007), 3.

15 Jesse Graham et al., "Moral Foundations Theory: The Pragmatic Validity of Moral Pluralism," in Advances in Experimental Social Psychology, First. (San Diego: Elsevier Inc., 2013), 59.

${ }^{16}$ K Bertens, Etika Profesi (Jakarta: PT Gramedia Pustaka Utama, 2020), 50.

17 Taylor W. Cyr and Matthew T. Flummer, "Free Will, Grace, and Anti-Pelagianism," International Journal for Philosophy of Religion 83, no. 2 (April 1, 2018): 192.
} 


\section{PAK Dalam Keluarga (X1)}

Keluarga adalah dua atau lebih dari dua individu yang tergabung karena hubungan darah, hubungan perkawinan. Hidup dalam suatu rumah tangga membutuhkan berinteraksi satu sama lain dan di dalam perannya masing-masing dan menciptakan serta mempertahankan suatu kebudayaan serta keharmonisan. ${ }^{18}$ Interaksi, keharmonisan, kehangatan di dalam iman memberikan pengajaran moral dan karakter tersendiri bagi anak.

Dikemukakan oleh Nurmalisa dan Adha bahwa kata moral acapkali merujuk kepada baik buruknya seseorang atau manusia sebagai manusia, sehingga bidang moral adalah bidang kehidupan manusia dilihat dari segi kebaikannya sebagai manusia. ${ }^{19}$ Manusia tidak bisa lepas dari kata 'moral', disebabkan oleh manusia mempunyai kesadaran untuk berbuat baik dan jahat. Darisitu Pembentukan moral kemudian dipahami menjadi suatu perilaku yang mengarahkan, menuntun, dan menjadikan sebagai bentuk moral dengan nilai, mendidik, membina, dalam merekayasa akhlak dan perilaku seseorang agar menghidupi, memahami dengan penghayatan penuh berbagai karakteristik yang baik.

Westermack memaparkan dengan singakt bahwa dalam diri seeorang telah ada sejenis ukuran moral untuk membedakan mana yang baik dan tidak baik. Pola itu akan terus diasah oleh kepercayaan/agama yang dianutnya sehingga kian teguh dalam penilaian sesuatu yang terjadi di dalam hidupnya. ${ }^{20}$ Dengan kata lain mematuhi aturanaturan moral yang mengubahnya pada sisi pemikiran, emosional dan tindakan nyata sehingga mempunyai habitus sesuai nilai-nilai moral yang berlaku dan telah diajarkan secara umum dalam aspek agama serta perundangan yang berlaku. Lickona memberikan tiga karakteristik pendidikan nilai/ moral yang mampu menghasilkan karakter baik yaitu moral knowing, moral feeling dan moral action.21

Tiga jenjang ini akan terjadi bila jenjang sebelumnya telah berhasil dilalui. Karena itu jenjang pertama dapat juga dipahami sebagai dasar untuk naik ke jenjang berikutnya. Adapun karakteristik nilai moral yang perlu ditanamkan/dibentuk kepada anak/siswa yaitu antara lain: nilai karakter religius, jujur, toleransi, disiplin, kerja keras, kreatif, mandiri, demokratis, rasa ingin tahu, semangat kebangsaan, cinta tanah air, menghargai prestasi, bersahabat/komunikatif, cinta damai, gemar membaca, peduli lingkungan, peduli sosial, dan tanggung jawab. Penelitian Gusman terhadap gerakan pentakosta di Afrika memberikan wawasan baru bagi pengajaran moral dan tingkah laku etis di kalangan anak muda, bahwa gerakan gereja mampu membentuk pemuda-pemudi gereja untuk kuat terhadap gempuran sekularitas berdasarkan ajaran-ajaran agama di gereja dan gerakan moral dari kalangan orang tua. ${ }^{22}$

${ }^{18}$ Eka Preskila and Bakhoh Jatmiko, "Keluarga Harmonis Berdasarkan Kolose 3:18-21 Dan Pengaruhnya Terhadap Etika Pergaulan Anak," Didache: Journal of Christian Education 1, no. 2 (2020): 166, https://journal.sttsimpson.ac.id/index.php/DJCE/article/view/345/pdf.

${ }^{19}$ Yunisca Nurmalisa and Muhammad Mona Adha, "Peran Lembaga Sosial Terhadap Pembinaan Moral Remaja Di Sekolah Menengah Atas," Jurnal Ilmiah Pendidikan Pancasila dan Kewarganegaraan 1, no. 1 (2016): 65 .

${ }^{20}$ Edward Alexander Westermarck, Christianity and Morals, 1st ebook. (London: Routledge, 2013), 16.

${ }^{21}$ Thomas Lickona, "Character Education: The Cultivation of Virtue," in Instructional-Design Theories and Models: A New Paradigm of Instructional Theory, ed. Francis Taylor (Mahwah, NJ: Erlbaum Associates, 2013), 563.

${ }^{22}$ Baca. Alessandro Gusman, "Moral Models, Self-Control and the Production of the Moral Citizen in the Ugandan Pentecostal Movement," in Christian Citizens and the Moral Regeneration of the African State, ed. Barbara Bompani and Caroline Valois, 1st ed. (London: Routledge, 2017), 166-182. 
PENGARUH PENDIDIKAN AGAMA KRISTEN DALAM KELUARGA ... (Pitri Sartika Sihotang, Hermanto Sihotang, Risa Ariska Tarigan

Keluarga adalah faktor terpenting dalam kehidupan. Suatu landasan yang diatasnya sikap dan keyakinan dibentuk. ${ }^{23}$ Dari pendapat beberapa ahli tersebut bagi peneliti keluarga adalah komponen penting bagi pembangunan bangsa. Keutuhan keluarga bisa menjadi indikasi keutuhan bangsa. Kekuatan keluarga bisa menjadi kekuatan bangsa. Kehancuran keluarga bisa menjadi indikasi kehancuran bangsa.

Dalam penelitiannya Hartono memaparkan tentang Keluarga memiliki peran yang terpercaya untuk menceritakan masalah yang dihadapi, mendiskusikan masalah, mematangkan anggota keluarga dalam emosional, hingga mendapatkan dukungan spiritual. ${ }^{24}$ Ini berarti bahwa orangtua perlu mengajarkan bagaimana berkomunikasi dan bagaimana kerjasama diantara anggota keluarga. Pengajaran ini dapat diberikan orangtua melalui peran ayah dan ibu dalam kesatuan membimbing anak-anak tanpa membeda-bedakan setiap pribadi anak dan tidak memilih kasih. Sebab tidak hanya ibu, seorang ayah juga mempunyai peranan yang penting dalam keluarga. Ayah sebagai kepala keluarga hendaknya terus mendidik anak dengan memberikan pendidikan yang terbaik dalam kondisi apapun. Tanggung jawab menjamin pendidikan anak didukung oleh ibu sebagai penolong karena keutuhan keluarga bergantung dalam kesatuan ide dan tindakan antara ayah dan ibu. Sebab itu dapat diartikan bahwa PAK Keluarga adalah pendidikan yang diajarkan oleh keluarga atau orangtua kepada anaknya tentang pengenalan akan Kristus.

\section{Fungsi Keluarga}

Hutahaean menyatakan bahwa orang tua adalah pribadi yang utama dan pertama dalam hidup anak. Kepribadian orang tua, sikap dan tata cara hidup mereka merupakan unsur-unsur yang dengan sendirinya masuk ke dalam pribadi yang tumbuh itu. ${ }^{25} \mathrm{Hal}$ ini dilakukan setiap hari. Untuk merealisasikan hal tersebut, maka harus dimulai dari komunikasi yang baik antar anggota keluarga untuk memberikan arahan dan bimbingan. Dari sini peneliti menduga bahwa hubungan anak dengan orang tua memiliki pengaruh bagi pertumbuhan dan perkembangan mental anak. Dengan berbagai hal seperti kontak mata, perhatian, diskusi-diskusi masalah yang dihadapai anak hingga masa kedewasaan, anak akan mempunyai pengalaman adanya hubungan yang hangat dalam lingkup keluarga. ${ }^{26}$ Merasa bahwa ia disayangi, diperhatikan, diperlakukan baik, dilindungi atau diperhatikan biasanya akan mudah menerima dan mengikuti kebiasaan orang tua dalam hal-hal positif.

Dari uraian di atas dapat disimpulkan bahwa PAK Keluarga merupakan pendidikan yang berpusat pada pengenalan akan Kristus yang dimulai dari satu rumah tangga atau kelompok terkecil dalam masyarakat dengan tujuan membimbing setiap pribadi untuk mengenal Kristus. Hutabarat juga menyatakan bahwa orang tua tak boleh lupa bahwa peran mereka adalah sebagai penyampai pendidikan keluarga yang berlangsung seumur hidup, khususnya selama anak tersebut bersama dengan mereka karena belum berkeluarga (berumah tangga). ${ }^{27}$ Upaya ini agar kelak anak-anak dapat menerapkan Pendidikan Agama Kristen dalam keluarga mereka sebagaimana telah terjadi dalam keluarga orang tuanya.

\footnotetext{
${ }^{23}$ Jaja Suteja, "DAMPAK POLA ASUH ORANG TUA TERHADAP PERKEMBANGAN SOSIALEMOSIONAL ANAK," AWLADY : Jurnal Pendidikan Anak 3, no. 1 (2017): 2.

${ }^{24}$ Baca. Handreas Hartono, "Membentuk Karakter Kristen Pada Anak Keluarga Kristen," Kurios 2, no. 1 (2014): 62-69, https://www.sttpb.ac.id/e-journal/index.php/kurios/article/view/22/23.

${ }^{25}$ Hasahatan Hutahaean, Akselerasi Guru Teologi Profesional Dan Bermutu (Medan, 2019), 170.

${ }^{26}$ Eirene Mary, "Implikasi Ulangan 5:16 Dalam Pendidikan Keluarga," Didache: Journal of Christian Education 1, no. 2 (2020): 145, https://journal.sttsimpson.ac.id/index.php/DJCE/article/view/331.

${ }^{27}$ Oditha R. Hutabarat, "MENDIDIK ANAK BERKARAKTER KRISTEN MENGATASI KEKERASAN," Voice of Wesley: Jurnal Ilmiah Musik dan Agama 1, no. 2 (2019): 6.
} 
Peneliti mengusulkan peran PAK dalam keluarga yang perlu diperhatikan adalah mengupayakan relasi yang harmonis serta kerjasama orang tua (ayah dan ibu) mendidik anak bersamaan dengan itu guna membangun keharmonisan sesama anggota keluarga. Oleh karena itu, Pasuhuk menandaskan bahwa keluarga adalah lingkungan utama dalam perjalanan pembentukan kompetensi sosial anak-anak demi "transformasi perilaku dan sikap." 28 Jadi, peranan ayak dan ibu sangat penting bagi kualitas anak dalam banyak sisi, bukan hanya belajar dan mengalami pertumbuhan di dalam keluarga, tetapi seluruh anggota keluarga dapat saling belajar dari anggota yang lain melalui interaksi yang hangat di rumah tiap hari. ${ }^{29}$ Bersamaan dengan itu, agar semuanya itu tidak mengecualikan orangtua untuk menjadi teladan di rumah terhadap anak-anak.

Dari uraian di atas, maka PAK dalam keluarga sangat mempengaruhi pembentukan moral seorang anak. Ndruru juga menuliskan bahwa dimana jika anak ditanamkan nilainilai Kristen sejak dini maka benteng imannya akan semakin kokoh dan dapat membentuk moralnya secara baik. Sikap baik atau buruk seorang anak dipengaruhi dari lingkungannya terutama lingkungan keluarganya karena anak akan cenderung meniru bagaimana sikap orangtuanya. ${ }^{30}$ Oleh sebab itu orangtua adalah sumber utama anak dalam pembentukan moralnya.

Selanjutnya, boleh saja remaja menerima masukan ajaran untuk pembentukan moral melalui khotbah yang diterimanya dari mengikuti rutinitasnya dalam beribadah dengan hikmad di gereja, dan melalui teman-temannya sesama remaja Kristen. Bisa juga dari pemberitaan firman Tuhan pada saat kegiatan kebaktian Kristen lainnya yang diikutinya misalnya: Kebaktian kategorial remaja, namun orang tua tidak boleh mengabaikan tugas dan tanggung jawabnya pertama-tama belajar dari berbagai sumber pembelajaran tentang ajaran PAK keluarga yang dapat dipakainya untuk menyelenggarakan dalam keluarga terhadap masa remajanya. Sehingga remajanya akan berminat untuk selalu menghormati hukum yang ke-4 yaitu mengenai pengudusan hari sabat dengan berkebaktian minggu setiap minggunya. Dwici Manik menyatakan mungkin tidak akan mengejutkan bahwa perilaku dan tindakan orang dewasa dalam kehidupan anak, akan memberikan pengaruh terbesar kepada perilaku anak terhadap rutinitas ibadahnya. ${ }^{31}$

\section{Rutinitas Ibadah di Sekolah (X2)}

Ibadah merupakan suatu bentuk kegiatan manusia dalam melakukan persekutuan kepada Allah sebagai ucapan syukur karena Allah telah memberikan kehidupan yang baik dalam hidup mereka. Sejalan dengan hal tersebut ternyata ibadah memiliki hal yang berarti terhadap moral serta sikap etis seseorang, khususnya bagi orang-orang Kristen. Arti dari mengikuti kebaktian atau ibadah sama dengan mereka datang untuk beribadah kepada Tuhan secara harfiah berarti bakti, hormat, penghormatan (homoge). Atau dapat juga dikatakan suatu penghormatan hidup yang mencakup kesalehan (yang diatur dalam suatu tata cara), yang implikasinya nampak dari tingkah laku dan aktifitas kehidupan sehari-hari. Fakta ini menyatakan kegagalan anak remaja, sebab setiap orang percaya (Kristen) yang mengecap pendidikan di sekolah pada umumnya mengadakan

${ }^{28}$ Novie D. S Pasuhuk, "Pendidikan Keluarga Yang Efektif," KURIOS (Jurnal Teologi dan Pendidikan Agama Kristen) 2, no. 1 (2014): 71, https://www.sttpb.ac.id/e-journal/index.php/kurios/article/view/23/24.

${ }^{29}$ Mary, "Implikasi Ulangan 5:16 Dalam Pendidikan Keluarga," 148.

${ }^{30}$ Sokhiziduhu Ndruru, "Pentingnya Pendidikan Agama Kristen Dalam Keluarga Sebagai Sentral Belajar Yang Bermisi," Voice of HAMI: Jurnal Teologi dan Pendidikan Agama Kristen 2, no. 1 (2019): 37, http://stthami.ac.id/ojs/index.php/hami/article/view/4/3.

${ }^{31}$ Novida Dwici Yuanri Manik, "Keluarga Sebagai Komunitas Utama Dalam Membentuk Kepribadian Anak," JURNAL LUXNOS 5, no. 1 (2019): 67,

https://luxnos.sttpd.ac.id/index.php/20_luxnos_20/article/view/dwici_2019/dwici_2019. 
PENGARUH PENDIDIKAN AGAMA KRISTEN DALAM KELUARGA ... (Pitri Sartika Sihotang, Hermanto Sihotang, Risa Ariska Tarigan

Penelahan Alkitab (PA) yang dilakukan setiap minggu di luar jam Pelajaran Agama Kristen dan Budi Pekerti. Pada bagian ini Guru di Sekolah didorong untuk menjadi mitra orang tua agar murid lebih dekat dengan orang tuanya. ${ }^{32}$ Dalam Roma 10:17 menegaskan bahwa hanya melalui pendengaran akan firman Allah, maka seseorang bisa memiliki iman kepada Yesus Kristus yang merupakan kekuatan dalam hidupnya untuk bertindak dan berbuat.

Menurut peneliti kekuatan yang dari Allah bukan begitu saja didapatkan oleh manusia, bukan juga sesuatu yang tersembunyi dari seseorang. Karena itu Firman Tuhan harus diberitakan agar manusia berdosa (dalam hal ini remaja) mendengarkan Injil dan percaya. Sejurus dengan ini Belo menyatakan dasar dan pijakan PAK adalah Alkitab. ${ }^{33}$ Karena itu remaja juga harus hidup sesuai dengan Roh dan dipenuhi oleh Roh. Analisa penting lainnya dari penelitian Simanjuntak bahwa mendengarkan Firman Allah bukanlah suatu kegiatan yang dilakukan sekali saja tetapi suatu tuntutan untuk terus menerus mendengarkan Firman Allah agar iman seseorang semakin percaya dan semakin bertumbuh serta semakin meningkat. ${ }^{34}$ Misalnya dapat di dengar melalui Penelahan Alkitab yang diadakan di rumah atau di sekolah. Oleh sebab itu rutinitas ibadah juga sangat mempengaruhi bagaimana pembentukan moral siswa. Jika seseorang itu rajin dalam beribadah mereka akan semakin dituntun untuk melakukan kebenaran yang sesuai dengan Firman Tuhan. Karena dalam rutinitas ibadah mereka, secara tidak langsung mereka telah memelihara imannya terhadap Tuhan dan berhubungan intim dengan Tuhan. Sehingga dari tingkah laku mereka akan terbentuk moral yang baik sebagai siswa Kristen yang aktif dalam beribadah.

\section{PAK Keluarga bagi Anak}

Pendidikan Agama Kristen dalam keluarga mempunyai tujuan mengajarkan hubungan manusia dengan sesama dan hubungan manusia terhadap Tuhan beserta ciptaan-Nya. Pendidikan Agama Kristen dapat berikan di dalam keluarga oleh orang tua, di sekolah oleh guru dan atau tempat ibadah tanpa batas ruang dan waktu. Selain itu, peran PAK hendaknya mengajarkan tentang kehidupan yang nyata kepada anak-anak, agar mengerti tentang tujuan kehidupan sesuai kehendak Tuhan. Pendidikan Agama Kristen dalam keluarga sedemikian penting diterapkan oleh orang tua untuk membekali anak dalam menghadapi falsafa hidup yang terus berubah. Salah satu peran pendidikan Agama Kristen dalam keluarga saat ini adalah mengupayakan kerjasama ayah dan ibu dalam mendidik anak serta menciptakan keharmonisan dalam keluarga. ${ }^{35}$ Oleh karena itu, keluarga merupakan lingkungan yang paling utama dalam melakukan pembentukan nilai-nilai religious dan sosial kepada anak-anak.

Penelitian Yeni juga memberikan nasihat terhadap hal di atas karena anak usia ini perlu pendampingan orang tua agar mereka tidak salah dalam menilai jati diri, kepribadian dan mengenal dirinuya. ${ }^{36}$ Jadi, peranan orang tua dalam mengasuh anak-

${ }^{32}$ Baca. Dyulius Thomas Bilo and Menarik Asal Niat Harefa, "UPAYA GURU PENDIDIKAN AGAMA KRISTEN DALAM MENINGKATKAN RELASI YANG BAIK ANTARA ANAK DAN ORANGTUA," Phronesis: Jurnal teologi dan Misi 2, no. 2 (2020): 1-29,

https://jurnal.sttsetia.ac.id/index.php/phr/article/view/36.

${ }^{33}$ Yosia Belo, "BUAH ROH DALAM GALATIA 5:22-23 DAN PENERAPANNYA BAGI PENDIDIKAN AGAMA KRISTEN,” JURNAL LUXNOS 6, no. 1 (2020): 89, https://luxnos.sttpd.ac.id/index.php/20_luxnos_20/article/view/30/16.

${ }^{34}$ Linda Zenita Simanjuntak, Malik Malik, and Hasahatan Hutahaean, "Efektifitas Strategi Pelayanan Pastoral Konseling Kepada Pasien Panti Rehabilitasi Narkoba," Evangelikal: Jurnal Teologi Injili dan Pembinaan Warga Jemaat 5, no. 1 (2021): 74, https://journal.sttsimpson.ac.id/index.php/EJTI/article/view/352.

${ }^{35}$ Preskila and Jatmiko, "Keluarga Harmonis Berdasarkan Kolose 3:18-21 Dan Pengaruhnya Terhadap Etika Pergaulan Anak," 155.

${ }^{36}$ Yeni Krismawati, "Teori Psikologi Perkembangan Erik H. Erikson Dan Manfaatnya Bagi Tugas Pendidikan Kristen Dewasa Ini," Kurios 2, no. 1 (2014): 50. 
anak sangatlah penting, bukan hanya anak belajar dan mengalami pertumbuhan di dalam keluarga, tetapi seluruh anggota keluarga dapat saling belajar dari yang lain melalui interaksi satu sama lain. Dengan PAK Keluarga religiusitas anak bertumbuh dan diyakini pertumbuhan ini akan menekan perilaku amoral kepada anak-anak. ${ }^{37}$ Akan tetapi, semuanya itu tidak lepas dari keteladanan orangtua dalam keluarga.

Orangtua tentu harus berusaha dengan segala cara untuk memperlakukan anaknya secara adil, benar dan penuh dengan kasih sayang. Tuhan Yesus memerintahkan kepada setiap anak untuk mentaati orangtua, baik maupun buruk sikap orangtua, Tuhan juga memperintahkan kepada orangtua untuk mendidik anak dengan didikan yang benar, orangtua harus adil kepada setiap anak memberikan hasih sayang yang sama, baik amengertipun buruk keadaannya, normal maupun cacat kondisinya kasih tetap nyata. Dalam penelitian Bambangan menekankan pengajaran benar dan salah, etika dan moral serta berdampak bagi masyarakat diawali dari pengajaran di keluarga. ${ }^{38}$ Sehingga wujud kehadiran orang Kristen di masyarakat bagai garam dan terang dapat tewujud.

Pendidikan kepada anak dapat dilakukan dengan hal sederhana misalnya cara berpakaian untuk lebih sopan, penting bagi anak untuk berpakaian, apalagi seorang anak wanita karena menunjukan kepribadian yang baik dengan berpakaian yang sopan, dan menjauhkan dari tindak kekerasan hal yang mendasar perlu diperhatikan oleh orangtua. Anak yang beretika baik yang akan memiliki keberhasilan hal itu terutama untuk menumbuhkan kerja yang baik.

\section{Ibadah Siswa}

Ibadah adalah pertemuan Tuhan dengan jemaat sebagai umat-Nya. Ia mencerminkan peristiwa yang berlangsung antara Tuhan dengan manusia dalam perjanjian yang diadakan dengan Dia. Dalam ibadah terjadi dialog antara Tuhan dengan manusia, Tuhan berfirman dan jemaat menjawab, Tuhan memberi dan jemaat menerima, serta mengucap syukur, Tuhan mengampuni dan jemaat memuji nama-Nya.

Menurut peneliti ibadah merupakan perbuatan keseharian dalam setiap kehidupan kita, dimana tindakan yang dilakukan merupakan tindakan yang baik yang sesuai dengan kehendak Tuhan. Setiap perbuatan kita merupakan wujud kasih dan hormat kita kepada Tuhan. Sehingga setiap tindakan yang dilakukan selalu mendatangkan kebaikan yang merupakan wujud ibadah yang dilakukan dalam setiap kehidupan kita sehari-hari. Bukan saja menyangkut bagaimana keteraturan hidup kita dalam berdoa dan melaksanakan kebaktian setiap minggunya. Tetap bagaimana wujud hidup kita sebagai orang percaya yang mau hidup sesuai dengan kehendak dan ketetapan Tuhan. Prinsip ini juga menjadi cakupan penting ibadah dalam Perjanjian Lama dan Perjanjian Baru dari studi Hutahaean, dengan tambahan keyakinan akan hadirnya Allah dalam ibadha itu. ${ }^{39}$

Ibadah yang benar itu diawali dari adanya pemahaman yang baik tentang ibadah itu sendiri. Dewasa ini banyak orang Kristen salah memahami ibadah. Mereka berpikir ketika datang beribadah, mereka akan mendapat hiburan. Ibadah yang kita lakukan adalah ibadah untuk menyembah Tuhan. Ibadah bukan bertujuan menyenangkan diri, membuat diri merasa nyaman, atau memenuhi kriteria standar dan selera terhadap diri

\footnotetext{
${ }^{37}$ Evi Aviyah and Muhammad Farid, "Religiusitas, Kontrol Diri Dan Kenakalan Remaja," Persona:Jurnal Psikologi Indonesia 3, no. 2 (2014): 127.

${ }^{38}$ Malik Bambangan, "IMPLEMENTASI MENJADI GARAM BAGI DUNIA MENURUT MATIUS 5:13," Phronesis: Jurnal teologi dan Misi 2, no. 1 (2020): 22-32, https://jurnal.sttsetia.ac.id/index.php/phr/article/view/30.

${ }^{39}$ Hasahatan Hutahaean, Bonnarty Steven Silalahi, and Linda Zenita Simanjuntak, "Spiritualitas Pandemik : Tinjauan Fenomenologi Ibadah DI Rumah," Evangelikal: Jurnal Teologi Injili dan Pembinaan Warga Jemaat 4, no. 2 (2020): 240, https://journal.sttsimpson.ac.id/index.php/EJTI/article/view/270.
} 
sendiri. Ibadah adalah untuk Tuhan, dan Tuhan yang menjadi pusat penyembahan. Jika Tuhan adalah pusat ibadah bagi orang percaya bagaimana seharusnya sikap manusia dalam beribadah yang benar? Bagi peneliti sikap yang benar ketika beribadah adalah memiliki sikap hati yang penuh kerinduan untuk bertemu dengan Tuhan (band. Neh 8:2). Selanjutnya sikap kedua penuh perhatian (Neh 8:4). Saat beribadah kita harus memusatkan perhatian kita kepada Tuhan saja dan tidak mempedulikan apapun di sekeliling kita. Sikap yang ketiga adalah penuh hormat (Neh 8:6-7).

Setelah melaksanakan ibadah yang benar seorang Kristen akan mengalami perubahan dalam hidupnya. Hasil ibadah dapat disebut benar jik menunjukkan perubahan hidup kita yang dimulai dengan memperbarui pikiran kita. Dan hasilnya orang percaya akan menerima pertobatan. Berbahagialah orang yang mendengar Firman Tuhan dan menaatinya serta bersedia untuk bertobat. Tuhan akan mengijinkan orang itu untuk menikmati hasil yang baik yaitu: berkat, kesembuhan, kesehatan, kebahagiaan, kekudusan, urapan Tuhan dan kuasa Tuhan dalam kehidupannya.

Orang tua adalah dua figur utama dan pertama dalam kehidupan anak. Karena kepribadian orang tua dilihat setiap hari dengan berbagai sikap dan tata cara hidupnya menjadi unsur-unsur yang dengan sendirinya masuk ke dalam pribadi anak dalam pertumbuhan itu. ${ }^{40}$ Dengan demikian agar pertumbuhan anak memiliki kualitas yang baik dan bercermin pada Alkitab maka harus dimulai dari komunikasi yang baik antar anggota keluarga seraya di dalamnya memberikan arahan Firman TUHAN dengan PA bersama atau hari-hari khusus. Kebiasaan ini akan membangun hubungan anak dan orang tua yang bermuarah kepada pengaruh pertumbuhan dan perkembangan mental dari akhlak anak. Dengan berbagai perhatian dan kedewasaan, anak akan merasakan adanya hubungan yang hangat dalam lingkup keluarga. Anak mempunyai perasaan disayangi, diperhatikan serta dilindungi dan mendapatkan perlakuan yang baik, akan memudahkan anak untuk menerima dan mengikuti kebiasaan orang tua dalam hal-hal yang positif. Keluarga yang merupakan pondasi dasar pengajaran agama (Kristen) dan baik buruknya sifat yang akan dihasilkan. Karena keluarga merupakan tempat pertama kali anak belajar mengenal kehidupannya, anak yang dasar pondasinya dari keluarga yang baik/harmonis akan terbawa sampai dewasa. ${ }^{41}$ Karena di dalam keluargalah anakanak akan merasa tentram dan nyaman untuk melakukan aktifitas kehidupannya.

Siswa yang senantiasa rindu untuk melakukan ibadah setiap minggunya maka dengan sendirinya mencerminkan perbuatan yang menunjukkan kesetiaan, perbuatan yang menyatakan tunduk dan hormat kepada Tuhan dan juga kepada orang tua selaku wakil Tuhan di dunia ini yang membimbing dan mengarahkan anaknya untuk Takut Akan Tuhan. Sebagai anak harus menaruh bakti terhadap orang tua; jika sudah mengaku ber-Tuhan, maka seharusnya bakti kepada-Nya; setia memperhambakan diri. Seturut dengan Smith yang menerangkan bahwa bagi kalangan evangelical ibadah berarti rasa tunduk dan khikmad; perbuatan baik, upacara di gereja yang di dalamnya berisi nyanyian dan doa. ${ }^{42}$ Semuanya yang dilakukan tersebut di atas akan berkontribusi terhadap pertumbuhan moral siswa ketika siswa itu akan menghadapi kesulitan dalam hidupnya maka siswa itu akan mencari Tuhan yang dia kenal melalui ibadah yang selalu diikutinya. Maka siswa yang selalu aktif mengikuti ibadah akan kelihatan dari sikap etisnya yang meniru dan meneladani sikap dan karakter Yesus yang selalu didengarnya dari mengikuti kebaktian minggu dan kebaktian lainnya yang menyampaikan firman

\footnotetext{
${ }^{40}$ Preskila and Jatmiko, "Keluarga Harmonis Berdasarkan Kolose 3:18-21 Dan Pengaruhnya Terhadap Etika Pergaulan Anak,” 164.

${ }^{41}$ Band. Bongsu Parhusip, Hasahatan Hutahaean, and Elda Theresia, "Penerapan Model Think-Pair and Share Dalam Meningkatkan Hasil Belajar PAK Pada Siswa SMP," Didache Jurnal Teologi dan Pendidikan Kristen 1, no. 2 (2020): 118, https://journal.sttsimpson.ac.id/index.php/DJCE/article/view/349.

${ }^{42}$ Gordon T. Smith, Evangelikal, Sakramental Dan Pentakostal Sifat Dan Praktik Gereja Seharusnya (Jakarta: Indonesia Cahaya Rahmat Empati, 2019), 137.
} 
Tuhan dimana Tuhan yang diketahui adalah Tuhan yang baik, taat, setia, mengasihi, dan sabar walaupun menderita. Dengan demikian Rutinitas Ibadah $\left(\mathrm{X}_{2}\right)$ memberikan Kontribusi terhadap Pembentukan Moral Siswa (Y).

\section{PAK Keluarga dan Ibadah Siswa bagi Moralitas Siswa}

Keluarga adalah dimana edukasi sejati berlangsung, yakni edukasi yang bertanggung jawab bersama. Dengan kata lain, dapat dikatakan bahwa ditengah-tengah keluargalah anak-anak belajar dan dibentuk untuk memiliki sikap dan karakter yang baik atau tidak baik.

Dalam keluarga yang takut akan Tuhan akan membentuk keluarga yang baik karena sejak dari awal Pendidikan Agama Kristen dalam keluarga sudah terlaksana dengan baik. Sehingga dengan adanya PAK keluarga maka dengan sendirinya akan berkontribusi terhadap pembentukan moral siswa yang merupakan bagian dari keluarga. Karena apa yang terjadi dalam kehidupan keluarga tersebut akan menjadi panutan yang merupakan perbuatan regenerasi dalam hidup anak secara berkesinambungan.

Selain PAK keluarga, rutunitas ibadah juga sangat mempengaruhi pembentukan moral siswa. Dimana ibadah merupakan bukti kepatuhan dan taat kepada Tuhan. Ibadah merupakan pertemuan Tuhan dengan jemaat-Nya yang terjadinya dialog antara Tuhan dengan manusia. Dengan terjadinya interaksi atau persektuan antara manusia dengan Tuhan akan menumbuhkan Iman siswa kepada Yesus Kristus sehingga siswa memiliki kekuatan di dalam Yesus dalam setiap tindakan yang dilakukan. ${ }^{43}$ Ibadah juga dapat menumbuhkan pribadi siswa menjadi lebih baik karena di dalam ibadah siswa akan diperkenalkan dengan Firman Tuhan, dengan tujuan supaya siswa menyadari tanggung jawabnya di dalam setiap tindakan yang dilakukan agar sesuai dengan buah-buah iman yang tertulis di Firman Tuhan agar nyata di dalam kehidupan siswa. Dengan seringnya mendengarkan Firman Tuhan dan bersekutu dengan Tuhan melalui ibadah yang dilakukan maka pembentukan moral siswa tersebut juga akan bertumbuh dengan baik. ${ }^{4}$

\section{Hasil Temuan}

Jika ada temuan penelitian yang ingin diuraikan atau dijelaskan secara detail. Setelah data masuk dan dideskripsikan dengan interval, maka hasil selanjutnya adalah sebagai berikut;

Tabel 7 Uji Kecenderungan Variabel $X_{1}$ (PAK Keluarga)

\begin{tabular}{|c|c|c|c|c|c|}
\hline Kls & \multicolumn{2}{|l|}{ Ketetapan } & Fo & Persentase & Katagori \\
\hline 1 & $>62,5+1,5(12.5)$ & $>82$ & 27 & $91 \%$ & Tinggi \\
\hline 2 & $\begin{array}{l}62,5 \mathrm{~s} / \mathrm{d} 62.5+1,5 \\
(12.5)\end{array}$ & $81-70$ & 2 & $6 \%$ & Cukup \\
\hline 3 & $62.5 \mathrm{~s} / \mathrm{d} 1,5(12.5)-62,5$ & $69-58$ & 1 & $3 \%$ & Kurang \\
\hline 4 & $<62,5 \mathrm{~s} / \mathrm{d} 1,5(12,5)$ & $<57$ & 0 & $0 \%$ & Rendah \\
\hline & & & 30 & $100 \%$ & \\
\hline
\end{tabular}

${ }^{43}$ Band. Jansakti Saddu Saly and Hasahatan Hutahaean, "PENGARUH KHOTBAH DALAM IBADAH MINGGU TERHADAP KEDEWASAAN IMAN JEMAAT DI GKSI MERAUKE,”Visio Dei: Jurnal Teologi Kristen 2, no. 2 (2020): 227-229, http://jurnal.sttstarslub.ac.id/index.php/js/article/view/165.

${ }^{44}$ Band. Hasahatan Hutahaean, "TINJAUAN BUKU Evangelikal, Sakramental Dan Pentakostal," Visio Dei: Jurnal Teologi Kristen 2 No.1, no. STT Star's Lub (2020): 176 Hutahaean memebrikan penekanan bagi kaum Injili dalam hal pemahaman Firman Tuhan menjadi salah satu sentral ibadah, yang menjadikannya berbeda dari kaum sakramental (katholik) dan pentakostal (sering disebut kharismatik). 
PENGARUH PENDIDIKAN AGAMA KRISTEN DALAM KELUARGA ... (Pitri Sartika Sihotang, Hermanto Sihotang, Risa Ariska Tarigan

Kecenderungan untuk Variabel X 1 (PAK Keluarga), berada pada kategori tinggi (91\%).

Tabel 8 Uji Kecenderungan Variabel $X_{2}$ (Rutinitas Beribadah Siswa)

\begin{tabular}{|c|l|c|c|c|c|}
\hline Kls & \multicolumn{2}{|c|}{ Ketetapan } & Fo & Persentase & Katagori \\
\hline 1 & $>62,5+1,5(12.5)$ & $>82$ & 28 & $94 \%$ & Tinggi \\
\hline 2 & $\begin{array}{l}62,5 \mathrm{~s} / \mathrm{d} 62.5+1,5 \\
(12.5)\end{array}$ & $81-70$ & 1 & $\%$ & Cukup \\
\hline 3 & $62.5 \mathrm{~s} / \mathrm{d} \mathrm{1,5}(12.5)-62,5$ & $69-58$ & 1 & $\%$ & Kurang \\
\hline 4 & $<62,5 \mathrm{~s} / \mathrm{d} 1,5(12,5)$ & $<57$ & 0 & $0 \%$ & Rendah \\
\hline & & & $\mathbf{3 0}$ & $\mathbf{1 0 0 \%}$ & \\
\hline
\end{tabular}

Kecenderungan untuk Variabel $\mathrm{X}_{2}$ (Rutinitas Beribadah Siswa), berada pada kategori Tinggi (94\%).

Tabel 9 Uji KecenderunganVariabel Y (Pembentukan Moral Siswa)

\begin{tabular}{|c|c|c|c|c|c|}
\hline No & \multicolumn{2}{|c|}{ Kelompok Interval } & Fo & Fr & Katagori \\
\hline 1 & $>60+1,5(12)$ & $>79$ & 29 & $97 \%$ & Tinggi \\
\hline 2 & $60 \mathrm{~s} / \mathrm{d} 60+1,5(12)$ & $78-66$ & 1 & $3 \%$ & Cukup \\
\hline 3 & $60 \mathrm{~s} / \mathrm{d} 1,5(12)-60$ & $65-54$ & 0 & $0 \%$ & Kurang \\
\hline 4 & $<60 \mathrm{~s} / \mathrm{d} 1,5(12)$ & $<53$ & 0 & $0 \%$ & Rendah \\
\hline & Jumlah & & $\mathbf{3 0}$ & $\mathbf{1 0 0} \%$ & \\
\hline
\end{tabular}

Kecenderungan untuk Variabel Y (Pembentukan Moral Siswa), juga berada pada kategori Tinggi (97\%).

Uji linieritas ini dilakukan untuk mengetahui kontribusi antara variabel bebas dengan variabel terikat. Dalam penelitian ini hipotesis yang diuji yaitu Variabel $\mathrm{X}_{1}$ (PAK Keluarga) dan Variabel $\mathrm{X}_{2}$ (Rutinitas Beribadah Siswa) terhadap Variabel $Y$ (Pembentukan Moral Siswa). Dalam penelitian ini variabel bebas mempunyai kontribusi yang berarti terhadap variabel terikat. Oleh karena itu, persamaan regresi yang perlu diuji kelinierannya dan keberartiannya masing-masing adalah seperti pada hasil di bawah ini:

Tabel 10 Ringkasan Persamaan Regresi Variabel $Y$ atas Variabel $X_{1}$

\begin{tabular}{|c|c|c|c|c|c|}
\hline Sumber Varians & $\mathrm{Dk}$ & $\mathrm{JK}$ & RJK & $\mathrm{Fh}$ & Ft $(\alpha=0,05)$ \\
\hline Total & 30 & 272298 & \multirow{2}{*}{268853.3} & \multirow{4}{*}{1,8} & \multirow{4}{*}{2,41} \\
\hline Regresi (a) & 1 & 268853.3 & & & \\
\hline Regresi (b/a) & 1 & 2346,1 & 2346,1 & & \\
\hline Residu (s) & 28 & 1098.6 & 39,2 & & \\
\hline Tunas Cocok (TC) & 18 & 840,7 & 46,7 & \multirow{2}{*}{59,8} & \multirow{2}{*}{4.17} \\
\hline $\mathrm{JK}(\mathrm{E})$ & 10 & 257,89 & 25,8 & & \\
\hline
\end{tabular}

Nilai dari pada $F_{\text {hitung }}=1$,8. Jika dikonsultasikan dengan $F_{\text {tabel }}$ pada taraf signifikan $5 \%$ dari derajat kebebasan $(\mathrm{dk})$ pembilang $=\mathrm{k}-2=18$ dan $\mathrm{dk}$ penyebut adalah $\mathrm{N}-\mathrm{K}=30$ $-20=10$, maka diperoleh harga $F_{\text {tabel }}=2,41$. Dengan demikian, maka nilai $F_{\text {hitung }}(1,8) \leq$ $\mathrm{F}_{\text {tabel }}(2,41)$. Maka, kesimpulannya adalah persamaan regresi: $\mathrm{Y}$ atas $\mathrm{X}_{1}$ adalah linear. Sementara itu, hasil perhitungan dari nilai $F_{\text {hitung }}$ adalah 59,8. Jika dikonsultasikan 
terhadap $F_{\text {tabel }}$ pada taraf signifikan 5\% dan derajat kebebasan $(\mathrm{dk})=1: 30$. Maka diperoleh kesimpulan bahwa harga $F_{\text {hitung }}(59,8) \geq F_{\text {tabel }}(4.17)$.

\section{Tabel 11 Ringkasan Analisis Varians Untuk Persamaan Regresi Variabel $Y$ atas Variabel $X_{2}$}

\begin{tabular}{|c|c|c|c|c|c|}
\hline Sumber Varians & Dk & JK & RJK & $\mathrm{Fh}$ & Ft $(\alpha=0,05)$ \\
\hline Total & 30 & 262361 & \multirow{2}{*}{258169,6} & \multirow{4}{*}{1,4} & \multirow{4}{*}{2,45} \\
\hline Regresi (a) & 1 & 258169,6 & & & \\
\hline Regresi (b/a) & 1 & 1700,69 & 1700,69 & & \\
\hline Residu (s) & 28 & 1744 & 62,3 & & \\
\hline Tunas Cocok (TC) & 20 & 1357,8 & 67,9 & \multirow{2}{*}{27,3} & \multirow{2}{*}{4.17} \\
\hline $\mathrm{JK}(\mathrm{E})$ & 8 & 386,17 & 48,3 & & \\
\hline
\end{tabular}

Diketahui bahwa nilai dari pada $F_{\text {hitung }}=1$,4. Maka dikonsultasikan dengan $F_{\text {tabel }}$ pada taraf signifikan $5 \%$ dari derajat kebebasan $(\mathrm{dk})$ pembilang $=\mathrm{k}-2=20$ dan $\mathrm{dk}$ penyebut adalah $\mathrm{N}-\mathrm{K}=30-22=8$, maka diperoleh harga $\mathrm{F}_{\text {tabel }}=2,45$. Dengan demikian, maka nilai $F_{\text {hitung }}(1,8) \leq F_{\text {tabel }}(2,45)$. Maka, kesimpulannya adalah persamaan regresi: $Y$ atas $\mathrm{X}_{2}$ adalah linear. Selain dari pada itu, hasil perhitungan dari nilai $\mathrm{F}_{\text {hitung }}$ adalah 27,3. Jika dikonsultasikan terhadap $\mathrm{F}_{\text {tabel }}$ pada taraf signifikan $5 \%$ dan derajat kebebasan $(\mathrm{dk})$ $=1: 30$. Maka diperoleh kesimpulan bahwa harga $F_{\text {hitung }}(27,3) \geq F_{\text {tabel }}(4.17)$. Dengan demikian maka dapat dinyatakan bahwa koefisien arah regresi $\mathrm{Y}$ ke $\mathrm{X}_{2}$ adalah berarti.

Sementara dari perhitungan nilai $F_{\text {hitung }}$ di atas, dapat dilihat bahwa nilai $F_{h}=5,5$. Dengan 1 variabel bebas maka, persamaan $F_{\text {hitung }}$ adalah 1:30 pada taraf signifikan 5\%, maka didapat bahwa $F_{\text {tabel }}$ sebesar 4,17 . Dengan demikian bahwa $F_{\text {hitung }}(5,5) \geq F_{\text {tabel }}$ $(4,17)$. Dengan demikian bahwa dapat disimpulkan bahwa Variabel $\mathrm{X}_{1}$ dan variabel $\mathrm{X}_{2}$ mempunyai persamaan regresi terhadap variabel $\mathrm{Y}$ secara bersama-sama, dengan persamaan regresi $\mathrm{Y}=82,65+0.59\left(\mathrm{X}_{1}\right)+0.46\left(\mathrm{X}_{2}\right)$.

\section{Pengujian Hipotesa}

Dengan berdasarkan dari pada hasil dari rekayasa data penelitian yang telah dilakukan, maka hipotesa yang telah diajukan di awal telah diuji dari dugaan sementara menjadi pembuktian temuan data. Dalam pengujian hipotesa ini, peneliti telah mengajukan tiga hipotesa dengan temuan penelitian. Oleh karena itu, dengan menggunakan rumus Korelasi Product Moment $\left(\mathrm{r}_{\mathrm{xy}}\right)$ dan menggunakan uji-t. Untuk memastikan kontribusi murni antara variabel diuji dengan Korelasi Parsial serta Korelasi Ganda.

Dari perhitungan nilai $r_{x y}$, didapatkan bahwa nilai dari rxyhitung $(0,825)$. Harga tersebut dikonsultasikan dengan nilai $\mathrm{r}_{\text {tabel }}$ untuk $\mathrm{N}=30$ dengan taraf signifikan $5 \%$, adalah 0,361 . Maka nilai dari $r_{\text {hitung }}(0,825) \geq r_{\text {tabel }}(0,361)$, sehingga korelasi $X_{1}$ dengan $Y$ adalah signifikan. Dari nilai tersebut diperoleh nilai determinasi $\mathrm{R}^{2}$ dimana $\mathrm{Rxy}^{2}$ $(0,825)^{2} \times 100=68,06 \%$. Dari perhitungan nilai $t_{\text {hitung }}$ diperoleh sebesar 7,6. Jika nilai tersebut dikonsultasikan dengan $t_{\text {tabel }}$ pada taraf signifikan $5 \% \mathrm{dk}=\mathrm{N}-2=28$, maka di dapatkan bahwa nilai $t_{\text {tabel }}$ pada taraf tersebut sebesar 1,701. Dengan demikian maka harga thitung $(7,6) \geq t_{\text {tabel }}(1,701)$. Dengan demikian, kontribusi dari variabel $X_{1}$ (PAK Keluarga) terhadap variabel Y (Pembentukan Moral Siswa) adalah berarti. Dengan kata lain terdapat pengaruh $\mathrm{X}_{1}$ terhadap $\mathrm{Y}$.

Dari perhitungan nilai $r_{x y}$, didapatkan bahwa nilai dari rxyhitung $(0,703)$. Harga tersebut dikonsultasikan dengan nilai $\mathrm{r}_{\text {tabel }}$ untuk $\mathrm{N}=30$ dengan taraf signifikan $5 \%$, adalah 0,361 . Maka nilai dari $r_{\text {hitung }}(0,703) \geq r_{\text {tabel }}(0,361)$, sehingga korelasi $X_{2}$ dengan $Y$ 
adalah signifikan. Dari nilai tersebut diperoleh nilai determinasi $\mathrm{R}^{2}$ dimana $\mathrm{Rxy}^{2}$ $(0,703)^{2} \times 100=49,37 \%$. Dari perhitungan nilai thitung diperoleh sebesar 5,22. Jika nilai tersebut dikonsultasikan dengan tabel pada taraf signifikan $5 \% \mathrm{dk}=\mathrm{N}-2=28$, maka di dapatkan bahwa nilai $t_{\text {tabel }}$ pada taraf tersebut sebesar 1,701. Dengan demikian maka harga $t_{\text {hitung }}(5,22) \geq t_{\text {tabel }}(1,701)$. Dengan demikian, kontribusi variabel $X_{2}$ (Rutinitas Beribadah Siswa) terhadap variabel Y (Pembentukan Moral Siswa) adalah berarti. Dengan kata lain terdapat pengaruh $\mathrm{X}_{2}$ terhadap $\mathrm{Y}$

Dari perhitungan korelasi ganda, diperoleh bahwa harga $\mathrm{R}^{2} \mathrm{y}_{12}$ adalah sebesar 0,289 . Dari harga tersebut dapat dibuktikan keberartiannya dimana nilai dari pada korelasi ganda tersebut dengan $\mathrm{dk}$ pembilang $=2$ (banyak variabel bebas) dan $\mathrm{dk}$ penyebut $=27(\mathrm{~N}-2-1)$ pada taraf signifikansi $5 \%$, diperoleh $F_{\text {tabel }}=4,19$. Dari hasil perhitungan, ternyata $F_{\text {hitung }}(7,2) \geq F_{\text {tabel }}(4,19)$. Perhitungan korelasi parsial Variabel $X_{2}$ (Rutinitas Beribadah Siswa) dengan Variabel Y (Pembentukan Moral Siswa) dan Variabel $\mathrm{X}_{1}$ (PAK Keluarga) dikontrol. Dari hasil perhitungan korelasi parsial, maka didapatkan bahwa nilai determinasi dari hasil tersebut adalah $\operatorname{Rxy}^{2}(0,333)^{2} \times 100=$ 11\%. Dari perhitungan nilai thitung diperoleh sebesar 1,8. Jika nilai tersebut dikonsultasikan dengan $t_{\text {tabel }}$ pada signifikansi $5 \%$ dengan dk-2-1 $=27$ diperoleh $t_{\text {tabel }}=$ 1,701 , maka didapatkan bahwa nilai $t_{\text {tabel }}$ pada taraf tersebut sebesar 1,701. Dengan demikian maka harga $t_{\text {hitung }}(1,8) \geq t_{\text {tabel }}(1,701)$. Dari perhitungan korelasi ganda, diperoleh bahwa harga $\mathrm{R}^{2} \mathrm{y}_{12}$ adalah sebesar 0,289. Untuk nilai keberartiannya diperoleh nilai $7,2, F_{\text {hitung }}(7,2) \geq F_{\text {tabel }}(4,19)$. Dengan demikian, kontribusi variabel $X_{1}$ (PAK Keluarga) dan variabel $\mathrm{X}_{2}$ (Rutinitas Beribadah Siswa) secara bersama-sama terhadap variabel Y (Pembentukan Moral Siswa) dikontrol adalah berarti. Dengan kata lain terdapat pengaruh secara bersama-sama $\mathrm{X}_{1}$ dan $\mathrm{X}_{2}$ terhadap $\mathrm{Y}$.

\section{Kesimpulan}

Penelitian telah membuktikan adanya pengaruh yang signifikan dari PAK di keluarga dan rutinitas beribadah siswa terhadap pembentukan moral siswa, baik secara parsial maupun bersama-sama sebesar 0,289. dan nilai keberartiannya diperoleh nilai 7,2 , $F_{\text {hitung }}(7,2) \geq F_{\text {tabel }}(4,19)$. Pentingnya PAK dalam keluarga patut untuk diperhatikan pelaksanaannya dengan tekun demi kelangsungan generasi yang bermoral di masa depan. Demikian juga bagi kegiatan ibadah di sekolah agar tidak jemu dalam melaksanakannya. Baik sekolah Negeri maupun sekolah Swasta. Peneliti menyarankan agar stakeholder di persekolahan memperhatikan segmen ini dengan memberikan masukkan yang penting dan terkait langsung pada pelaksanaan ibadah di sekolah sesuai dengan agama Kristen (bagi pemeluknya). Penelitian ini perlu kajian lanjutan dengan bidang yang lebih luas serta tinjauan literature yang lebih variatif. Jika memungkinkan dengan menggabungkan variable lainnya untuk menolong generasi masa depan memiliki moral dan akhlak yang seturut Firman Tuhan.

\section{Referensi}

AR, Muchson, and Samsuri Samsuri. DASAR-DASAR PENDIDIKAN MORAL. Yogyakarta: Penerbit OMBAK, 2013.

Arikunto, Suharsimi. Prosedur Penelitian : Suatu Pendekatan Praktik (Edisi Revisi). Rineka Cipta. Revisi. Jakarta: PT. Rineka Cipta, 2012.

Aviyah, Evi, and Muhammad Farid. "Religiusitas, Kontrol Diri Dan Kenakalan Remaja."

Persona:Jurnal Psikologi Indonesia 3, no. 2 (2014): 126-129. 
Bambangan, Malik. "IMPLEMENTASI MENJADI GARAM BAGI DUNIA MENURUT MATIUS 5:13." Phronesis: Jurnal teologi dan Misi 2, no. 1 (2020): 22-32. https://jurnal.sttsetia.ac.id/index.php/phr/article/view/30.

Belo, Yosia. "BUAH ROH DALAM GALATIA 5:22-23 DAN PENERAPANNYA BAGI

PENDIDIKAN AGAMA KRISTEN.” JURNAL LUXNOS 6, no. 1 (2020): 89-95.

https://luxnos.sttpd.ac.id/index.php/20_luxnos_20/article/view/30/16.

Bertens, K. Etika. Kesepuluh. Jakarta: PT Gramedia Pustaka Utama, 2007.

- - Etika Profesi. Jakarta: PT Gramedia Pustaka Utama, 2020.

Bilo, Dyulius Thomas, and Menarik Asal Niat Harefa. "UPAYA GURU PENDIDIKAN AGAMA KRISTEN DALAM MENINGKATKAN RELASI YANG BAIK ANTARA ANAK DAN ORANGTUA." Phronesis: Jurnal teologi dan Misi 2, no. 2 (2020): 1-29. https://jurnal.sttsetia.ac.id/index.php/phr/article/view/36.

Braga, Anthony A., David M. Hureau, and Andrew V. Papachristos. "An Ex Post Facto

Evaluation Framework for Place-Based Police Interventions." Evaluation Review 35, no. 6 (2012): 592-626.

Cyr, Taylor W., and Matthew T. Flummer. "Free Will, Grace, and Anti-Pelagianism." International Journal for Philosophy of Religion 83, no. 2 (April 1, 2018): 183-199. Graham, Jesse, Jonathan Haidt, Sena Koleva, Matt Motyl, Ravi Iyer, Sean P. Wojcik, and Peter H. Ditto. "Moral Foundations Theory: The Pragmatic Validity of Moral Pluralism." In Advances in Experimental Social Psychology, 55-130. First. San Diego: Elsevier Inc., 2013.

Gusman, Alessandro. "Moral Models, Self-Control and the Production of the Moral Citizen in the Ugandan Pentecostal Movement." In Christian Citizens and the Moral Regeneration of the African State, edited by Barbara Bompani and Caroline Valois, 166-182. 1st ed. London: Routledge, 2017.

Hartono, Handreas. "Membentuk Karakter Kristen Pada Anak Keluarga Kristen." Kurios

2, no. 1 (2014): 62-69. https://www.sttpb.ac.id/e-

journal/index.php/kurios/article/view/22/23.

Hutabarat, Oditha R. "MENDIDIK ANAK BERKARAKTER KRISTEN MENGATASI

KEKERASAN.” Voice of Wesley: Jurnal Ilmiah Musik dan Agama 1, no. 2 (2019): 1-23.

Hutahaean, Hasahatan. Akselerasi Guru Teologi Profesional Dan Bermutu. Medan, 2019.

___. "TINJAUAN BUKU Evangelikal, Sakramental Dan Pentakostal." Visio Dei: Jurnal Teologi Kristen 2 No.1, no. STT Star's Lub (2020): 175-179.

Hutahaean, Hasahatan, Hermanto Sihotang, and Purnamasari Siagian. "PAK Dalam Keluarga Dan Lingkungan Pergaulan Siswa, Kontribusinya Terhadap Pembentukan Karakter." Berita Hidup 3, no. 2 (2021): 171-188. https://ejournal.sttberitahidup.ac.id/index.php/jbh/article/view/84.

Hutahaean, Hasahatan, Bonnarty Steven Silalahi, and Linda Zenita Simanjuntak. "Spiritualitas Pandemik : Tinjauan Fenomenologi Ibadah DI Rumah." Evangelikal: Jurnal Teologi Injili dan Pembinaan Warga Jemaat 4, no. 2 (2020): 234-249. https://journal.sttsimpson.ac.id/index.php/EJTI/article/view/270.

Kassa, Enos Bonny. Etika Dan Moral ASN Di Masa Pandemi Covid-19. Edited by Wulansari Apriani. Bogor: CV. Dandelion Publisher, 2021.

Krismawati, Yeni. "Teori Psikologi Perkembangan Erik H. Erikson Dan Manfaatnya Bagi Tugas Pendidikan Kristen Dewasa Ini." Kurios 2, no. 1 (2014): 46-56.

Lickona, Thomas. "Character Education: The Cultivation of Virtue." In InstructionalDesign Theories and Models: A New Paradigm of Instructional Theory, edited by Francis Taylor, 591-612. Mahwah, NJ: Erlbaum Associates, 2013.

Manik, Novida Dwici Yuanri. "Keluarga Sebagai Komunitas Utama Dalam Membentuk Kepribadian Anak." JURNAL LUXNOS 5, no. 1 (2019): 61-71. 
PENGARUH PENDIDIKAN AGAMA KRISTEN DALAM KELUARGA ... (Pitri Sartika Sihotang, Hermanto Sihotang, Risa Ariska Tarigan

https://luxnos.sttpd.ac.id/index.php/20_luxnos_20/article/view/dwici_2019/dwic i_2019.

Mary, Eirene. "Implikasi Ulangan 5:16 Dalam Pendidikan Keluarga." Didache: Journal of Christian Education 1, no. 2 (2020): 141-152.

https://journal.sttsimpson.ac.id/index.php/DJCE/article/view/331.

Ndruru, Sokhiziduhu. "Pentingnya Pendidikan Agama Kristen Dalam Keluarga Sebagai

Sentral Belajar Yang Bermisi." Voice of HAMI: Jurnal Teologi dan Pendidikan Agama Kristen 2, no. 1 (2019): 32-44.

http://stthami.ac.id/ojs/index.php/hami/article/view/4/3.

Nurmalisa, Yunisca, and Muhammad Mona Adha. "Peran Lembaga Sosial Terhadap Pembinaan Moral Remaja Di Sekolah Menengah Atas." Jurnal Ilmiah Pendidikan Pancasila dan Kewarganegaraan 1, no. 1 (2016): 74-71.

Parhusip, Bongsu, Hasahatan Hutahaean, and Elda Theresia. "Penerapan Model ThinkPair and Share Dalam Meningkatkan Hasil Belajar PAK Pada Siswa SMP." Didache Jurnal Teologi dan Pendidikan Kristen 1, no. 2 (2020): 117-140. https://journal.sttsimpson.ac.id/index.php/DJCE/article/view/349.

Pasuhuk, Novie D. S. "Pendidikan Keluarga Yang Efektif." KURIOS (Jurnal Teologi dan Pendidikan Agama Kristen) 2, no. 1 (2014): 70-81. https://www.sttpb.ac.id/ejournal/index.php/kurios/article/view/23/24.

Preskila, Eka, and Bakhoh Jatmiko. "Keluarga Harmonis Berdasarkan Kolose 3:18-21 Dan Pengaruhnya Terhadap Etika Pergaulan Anak." Didache: Journal of Christian Education 1, no. 2 (2020): 153-168. https://journal.sttsimpson.ac.id/index.php/DJCE/article/view/345/pdf.

Rahman, Yenni. Nilai-Nilai Agama Dan Moral: Kerukunan Beragama-Pegangan Murid/Anak. Tangerang: Tirtamedia, 2021.

Saly, Jansakti Saddu, and Hasahatan Hutahaean. "PENGARUH KHOTBAH DALAM IBADAH MINGGU TERHADAP KEDEWASAAN IMAN JEMAAT DI GKSI MERAUKE.” Visio Dei: Jurnal Teologi Kristen 2, no. 2 (2020): 225-243. http://jurnal.sttstarslub.ac.id/index.php/js/article/view/165.

Simanjuntak, Linda Zenita, Malik Malik, and Hasahatan Hutahaean. "Efektifitas Strategi Pelayanan Pastoral Konseling Kepada Pasien Panti Rehabilitasi Narkoba." Evangelikal: Jurnal Teologi Injili dan Pembinaan Warga Jemaat 5, no. 1 (2021): 6779. https://journal.sttsimpson.ac.id/index.php/EJTI/article/view/352.

Smith, Gordon T. Evangelikal, Sakramental Dan Pentakostal Sifat Dan Praktik Gereja Seharusnya. Jakarta: Indonesia Cahaya Rahmat Empati, 2019.

Sugiyono, Sugiyono. Metode Penelitian Kuantitatif. Bandung: AlfaBeta, 2018.

SUMARA, DADAN SUMARA, SAHADI HUMAEDI, and MEILANNY BUDIARTI SANTOSO. "Kenakalan Remaja Dan Penanganannya." Prosiding Penelitian dan Pengabdian kepada Masyarakat 4, no. 2 (2017): 129-389.

Suprapto, Haddy. Penerapan Metodologi Penelitian Dalam Karya Ilmiah. Yogyakarta: Gosyen Publishing, 2020.

Suteja, Jaja. "DAMPAK POLA ASUH ORANG TUA TERHADAP PERKEMBANGAN SOSIALEMOSIONAL ANAK." AWLADY : Jurnal Pendidikan Anak 3, no. 1 (2017): 1-14.

Westermarck, Edward Alexander. Christianity and Morals. 1st ebook. London: Routledge, 2013.

Whidmurni, Whidmurni. "Penelitian Kuantitatif." Pemaparan Metode Penelitian Kuantitatif 2, no. 16 (2017): 1-16. http://repository.uinmalang.ac.id/1985/2/1985.pdf. 